\title{
A Linguistic Decision Model to Suppliers Selection in International Purchasing ${ }^{1}$
}

\author{
Francisco Herrera*, Enrique López**, Cristina Mendaña** and \\ Miguel A. Rodríguez**
}

*Computer Science and Artificial Intelligence Department

University of Granada

18071 Granada, Spain

herrera@decsai.ugr.es

** Economy and Business Management Department

University of León

24071-León, Spain

dde $\{\mathrm{elg} / \mathrm{cmc} / \mathrm{mrf}\} @$ unileon.es

\begin{abstract}
The traditional approach to suppliers selection based on price is simplistic because the information held for the decision making model is more complex and without precision in some tasks. There are qualitative factors that demand some judgement to determine a suppliers selection. Therefore, the linguistic representation of the of the knowledge available allows the problem to be recognised as in real life. This paper aims to supply a linguistic decision model to purchasing management problems.
\end{abstract}

KEY WORDS: global sourcing, purchasing, suppliers selection, relationships between inputs, linguistic labels, linguistic operators, linguistic decision model.

\section{INTRODUCTION}

In recent years, purchasing has undergone a total change of perspective: from an operational function to a strategic one. To cope with the increased significance of purchasing and environmental uncertainties, buyers should no longer just be processors of requisitions and order forms, but increasingly need to take on strategic roles within organisations. They take part in decisions concerning supply chain management, product input supplies alternatives for the firm and they participate in future strategy formulation processes. In doing so, purchasing decision-making is improved.

As importance of purchasing decisions has increased, so has the basis of these decisions. Due to the increased attention of top management for the purchasing function, purchasing managers more and more are confronted with questions concerning the rational justifications of their decisions and the

${ }^{1}$ This research has been partially supported by DGICYT PB95-0058 
corresponding supply performance At the same time, as a result of the more complex, dynamic, turbulent and volatile industrial environment, the complexity and opaqueness of this decision making basis has increased as well.

As purchasing has an important effect on the profitability of an organisation and forms a potential source of profit for many industrial companies, purchasing should be a well-equipped, professional organisational function and an integrated part in the organisation [Van Weele, 1994]. So, a professional approach of purchasing decisions contributes to seizing opportunities that can result in savings as well as a competitive advantage for an organisation. It is essential to today's performance of an organisation as a whole that these benefits achievable through good purchasing practices are obtained. This includes the use of sound decision making bases in purchasing.

Shortly, purchasing is the "process of buying". Identifying and selection suppliers are the most important responsibilities of the purchasing department. Purchasing managers and other charged with determining the standards attained by each supplier in the requirements needed for the demanded good prefer to use natural language for it. This is because it is quite divorced from reality to express these standards in terms of strict numerical values. Using linguistic information, natural linguistic labels, may lead to the loss of precision that numbers can give, but there is a positive counterpart in grater closeness to the problem [Zadeh, 1975].

The objective of this paper is to supply a linguistic decision model to suppliers selection. In order to do that, the paper is organized as follows. Section 2 introduces the suppliers selection problem; Section 3 presents a fuzzy linguistic model for suppliers selection; Section 4 proposes a bicriteria linguistic selection model to choose the suppliers; Section 5 presents an illustrative practical application; and Section 6 points out some concluding remarks.

\section{SUPPLIERS SELECTION}

\subsection{Purchasing Objectives and Functions}

Purchasing is the "process of buying". It is widely assumed that purchasing is exclusively responsibility of the purchasing department. However, the function is much broader and, if is carried out effectively, all departments in the company are involved. Obtaining the right material, in the right quantities, with the right delivery (time and place), from the right source, and at the right price are all purchasing functions.

Choosing the right material requires input from the marketing, engineering, manufacturing, and purchasing departments. Quantities and delivery of finished goods are established by the needs of the market. However, manufacturing planning and control must decide when to order which raw materials so that market demands can be satisfied. Purchasing department is, therefore responsible for placing the orders and for ensuring that the goods arrive on time.

The purchasing department has the major responsibility for locating suitable sources of supply and for negotiating prices. Input from other departments 
are required for finding and evaluating sources of supply and for helping the purchasing department in price negotiation.

Purchasing is responsible for establishing the flow of materials into the firm, following-up with the supplier, and expediting delivery. Missed deliveries can create havoc with manufacturing and sales, but purchasing can reduce problems for both areas, further adding to the profit.

The objectives of purchasing can be divided into four categories [Arnold, 1996]:

- Obtaining goods and services of the required quantity and quality.

- Obtaining goods and services at the lowest cost.

- Ensuring the best possible service and prompt delivery by the supplier.

- Developing and maintaining good supplier and developing potential suppliers.

To satisfy these objectives, some basic functions must be performed:

- Determining purchasing specifications: right quality, right quantity, and right delivery (time and place).

- Selecting supplier (right source).

- Negotiating terms and conditions of purchase.

- Issuing and administration of purchase orders

Identifying and selecting suppliers are the most important responsibilities of the purchasing department, since it makes use of all the information available from the other functions. So, our paper aims to give a solution to select the suppliers team that maximise the purchasing utility when the information on held is complex, imprecise or vague.

\subsection{Suppliers Selection in an Atmosphere of Uncertainty Descriptive Analysis and Modeling of the Problem}

The objective of purchasing is to gather all the right things together: quality, quantity, delivery, and price. Once the decision is made about what to buy, the selection of the right supplier is the next most important purchasing decision. A good supplier is the one that has the technology to make the product to the required quality, has the capacity to make the quantities needed, and can run the business well enough to make a profit and still sell a product competitively.

The previous section discussed the importance of functions, quality, service and price specifications. These are what the supplier is expressed to provide and are the basis for selection and evaluation. Considering this, there are several factors in selecting a supplier [Arnold, 1996]:

- Technical ability. The supplier must have the technical ability to make or supply the product wanted. Also, he has to assist in improving the products and have a program of product development and improvement. These capacities are important since, often, the buyer will depend upon the supplier to provide product improvements that will enhance or reduce the cost of the buyer's products. Sometimes the supplier can suggest 
changes in product specifications that will improve the product and reduce the cost.

- Manufacturing capability. Manufacturing must be able to meet the specifications for the product consistently while making as few flaws as possible. This means that the supplier's manufacturing facilities must be able to supply the quality and quantity of the products wanted. The supplier must have a good quality control program, competent and capable manufacturing personnel, and good manufacturing planning and control systems to ensure on time delivery. These are important in ensuring that the supplier can provide the quality and quantity wanted.

- Reliability. In selecting a supplier, it is desirable to choose a reputable, stable, and financially strong one. If the relationship is to continue, there must be an atmosphere of mutualtrust and assurance that the supplier is financially strong enough to stay in business.

- After sales service. If the product is of a technical nature or likely to need replacement parts or technical support, the supplier must have a good after-sales service. This should include a good service organisation and inventory of service parts.

- Supplier location. Sometimes it is desirable that the supplier is located near the buyer, or at least maintain an inventory locally. A close location helps to shorten delivery times and means emergency shortages can delivery quickly.

- Price. The supplier should be able to provide competitive prices. This does not necessarily mean the lowest price. It is the one that takes into account the ability of the supplier to provide the necessary goods in the quantity and quality wanted, at the time wanted, as well as any other services needed.

- Other considerations. Sometimes other factors such as credit terms, reciprocal business, and willingness of the supplier to hold inventory for the buyer should be considered.

Some factors in evaluating potential suppliers are quantitative. Price is the obvious example. On the other hand, there are qualitative factors that demand some judgement to determine them. These are usually set out in a descriptive fashion. The supplier's technical competence might be an example.

The challenge is finding some method of combining these two major factors that will enable a buyer to choose the best suppliers.

Thus, if the best possible value is to be achieved from suppliers selection, this must not merely consider the requirements of each of the goods and suppliers to be chosen, in comparison with the capacities of the candidates for suppliers. It should also address the compatibility of the suppliers, because if they are chosen they will belong to a team made up of suppliers with whom they must get along in order to achieve a common goal.

An attempt to collect and evaluate all this information arises interest in the possible application here of the theory of fuzzy sets [Zadeh, 1965; Kufmann and Gil-Aluja, 1992] with the aim of being able to handle suitably the uncertainty which is characteristic of the decision-making processes in suppliers selection. This paper specifically proposes the use of linguistic labels to represent the 
information on these variables and lead to a decision-making model, which is able to handle such information, [Zadeh, 1995].

In addition, if the problem is selecting suppliers for several goods, then those inputs of greatest importance for the purchasing management should be weighted in some way, as these are the ones which should be most effectively matched to the ideal supplier.

Referring to the relationship liaisons along a supply chain we can have two main different typologies of structures: a tree structure and a network structure [Bellandi et al., 1997]. The first one, shown in Figure 1, is made by a master company, which produces the finished product and attends to its marketing, makes up the tree structure, by first level suppliers. So, in the tree structure there is only vertical teamwork liaisons, therefore do not occur side liaisons between suppliers.

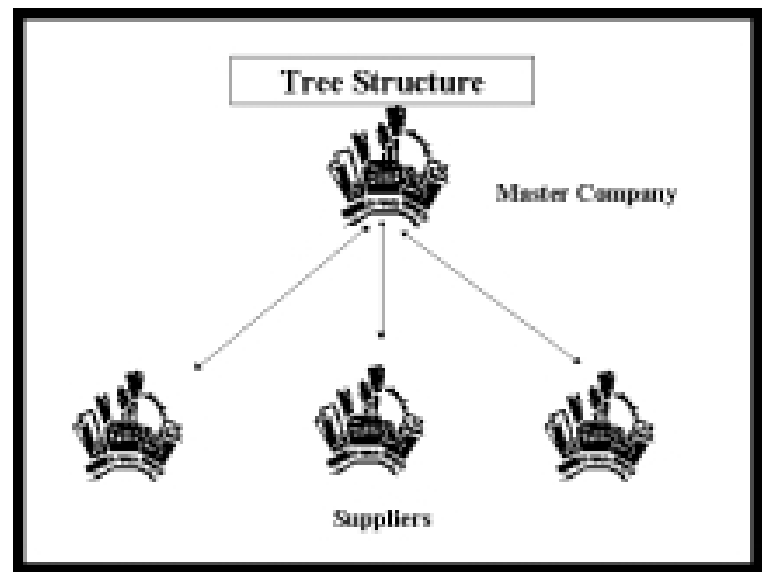

Figure1

On the other hand, in the network structure, shown in Figure 2, we find both vertical and horizontal liaisons.

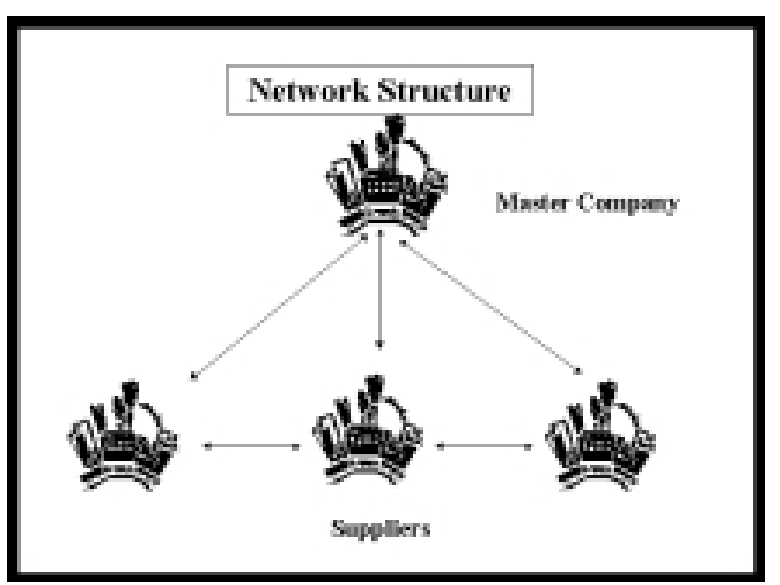

Figure 2 
In this work we are referring to the network structure because include the tree one. This justifies looking into the possible relationships among demanded goods, and into the level of compatibility between suppliers, during the selection process. Such considerations are often made in a subjective way, so that the use of linguistic labels would allow greater closeness to the realities of the decisionmaking procedure being investigated.

Once the degree to which each candidate for supplier has a given ability is established, this is compared to the capacities stated in the profile set up for the good demanded in question. This shows how far each candidate matches up to them, and allows an order of preference among candidates to be drawn up, though not without taking into account their compatibility, which is an objective in parallel with the good match of candidates for supplier to the requirements.

\section{FUZZY-LINGUISTIC MODEL FOR SUPPLIERS SELECTION}

\subsection{Linguistic Information}

Normally, in a quantitative situation the information required is expressed as numerical values. However, when working in qualitative areas such as purchasing management, which are characterised by vague or imprecise knowledge, the information cannot be set out in a precise numerical way. Thus, it would be a more realistic approach to use linguistic information instead of numbers, provided that the variables involved in the problem lend themselves to expression in this manner [Zadeh, 1975].

A linguistic variable differs from a numerical one in that its values are not numbers, but words or sentences in a natural or artificial language. Since words, in general, are less precise than numbers, the concept of a linguistic variable serves the purpose of providing a means of approximated characterisation of phenomena, which are too complex, or too ill-defined to be amenable to their description in conventional quantitative terms.

Usually, depending on the problem domain, an appropriate linguistic term set is chosen and used to describe the vague or imprecise knowledge. The elements in the term set will determine the granularity of the uncertainty, that is the level of distinction among different counting of uncertainty. Bonissone and Decker studied the use of term sets with an odd cardinal, representing the mid term an assess of "approximately 0.5 ", with the rest of the terms being placed symmetrically around it and the limit of granularity 11 or no more than 13 [Bonissone and Decker, 1986].

On the other hand, the semantic of the elements in the term set is given by fuzzy numbers defined on the $[0,1]$ interval, which are described by membership functions. Because the linguistic assessments are just approximate ones given by the individuals, we can consider that linear trapezoidal membership functions are good enough to capture the vagueness of those linguistic assessments, since it may be impossible or unnecessary to obtain more accurate values. This representation is achieved by the 4-tuple $\left(a_{i}, b_{i}, \alpha_{i}, \beta_{i}\right)$, the first two parameters indicate the interval in which the membership value is 1 ; the third and fourth parameters indicate the left and right width. Formally speaking, it seems difficult to accept that all individuals should agree on the same membership 
function associated to linguistic terms, and therefore, there are not any universality distribution concepts.

This paper supports the possibility of establishing in linguistic terms the information relating to the weighting of the requirements needed. It would appear clear that a purchasing manager might not know in a precise numerical way what the weighting for a requirement is, but could indicate it in normal linguistic terms. To estimate weightings, and indeed other features, it has been chosen to use a set of nine linguistic labels [Bonissone and Decker, 1986]. A graphical example is shown in Figure 3.

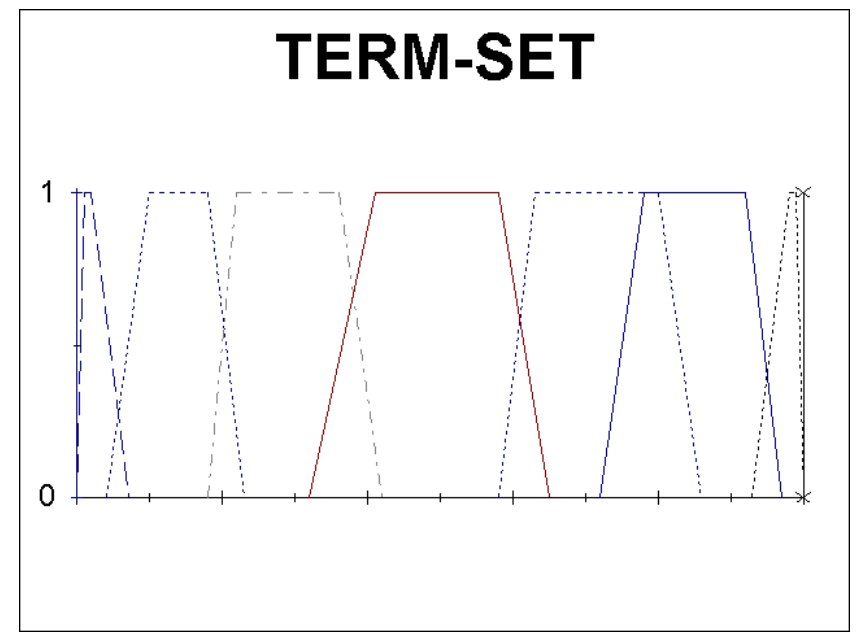

Figure 3

And the 4-tuples associated are:

$\begin{array}{ll}\text { E } & \text { Essential } \\ \text { VH } & \text { Very High } \\ \text { FH } & \text { Fairly High } \\ \text { H } & \text { High } \\ \text { M } & \text { Moderate } \\ \text { L } & \text { Low } \\ \text { FL } & \text { Fairly Low } \\ \text { VL } & \text { Very Low } \\ \text { U } & \text { Unnecessary }\end{array}$

$(1,1,0,0)$

$(.98, .99, .05, .01)$

$(.78, .92, .06, .05)$

$(.63, .80, .05, .06)$

$(.41, .58, .09, .07)$

$(.22, .36, .05, .06)$

$(.1, .18, .06, .05)$

$(.01, .02, .01, .05)$

$(0,0,0,0)$

\subsection{Linguistic Decision Model for Suppliers Selection}

The model proposed here consists of the following phases:

1. Goods demanded requirements. Step one is to determine for what goods are demanded. 


$$
G=\left\{G_{1}, G_{2}, \ldots, G_{m}\right\}
$$

Each good has also associated several requirements, such as quality, delivery, etc.:

$$
R=\left\{R_{1}, R_{2}, \ldots, R_{p}\right\}
$$

together with the weighting that each requirement has for the demanded goods

$$
I R=\left\{\begin{array}{cc}
I R_{11}, \ldots, I R_{1 p} \\
\vdots & \vdots \\
I R_{m 1}, \ldots, I R_{m p}
\end{array}\right\}, I R_{i j} \in W
$$

For the feature weighting, the labels that are proposed are the following:

$$
\begin{gathered}
W=\{\text { Essential, Very High, Fairly High, High, Moderate, } \\
\text { Low, Fairly Low, Very Low, Unnecessary }\}
\end{gathered}
$$

In addition, when suppliers are being selected for several goods, the purchasing manager or decision-maker may consider that not all of the goods have the same importance, and prefer solutions aimed at putting the most suitable supplier into the most crucial good. For this reason, a label associated with each position must be included to show the weighting that the good has for the recruitment procedure, which is under way. This characteristic is defined in this paper in exactly the same way as requirements, that is, with nine labels.

$$
I G=\left\{I G_{1}, I G_{2}, \ldots, I G_{m}\right\}, I G_{i} \in W
$$

Moreover, since the goods are not independent of one another, the links between them should be analysed, as also the weighting of such links. Here, too, the use of nine labels is felt appropriate.

$$
R G=\left\{\begin{array}{lc}
-, R G_{12}, \ldots . ., R G_{1 m} \\
\vdots & \vdots \\
R G_{m 1}, \ldots, R G_{m m-1}-
\end{array}\right\}, R G_{i j} \in W
$$

2. Suppliers levels and relationships. Once the demanded goods have been characterised, the candidates for suppliers are considered, $S=\left\{S_{1}, S_{2}, \ldots, S_{n}\right\}$. Information relating to them includes two types:

- the operational levels, which they demonstrate in the varying requirements needed for the demanded goods,

$$
L=\left\{\begin{array}{lc}
L_{11}, \ldots, L_{1 p} \\
\vdots & \vdots \\
L_{n 1}, \ldots, L_{n p}
\end{array}\right\}, L_{i j} \in L L
$$

with the next set of labels associated: 


\section{$L L=\{$ Optimum, Very High, Fairly High, High, Moderate, Low, Fairly Low, Very Low, Lowest\}}

- $\quad$ and the relationships linking suppliers with one another:

$$
R S=\left\{\begin{array}{lc}
-, R S_{12}, \ldots, R S_{1 n} \\
\vdots & \vdots \\
R S_{n 1}, \ldots, R S_{n n-1},-
\end{array}\right\}, R S_{i j} \in R
$$

with the next set of labels associated:

$R=\{$ Excellent, Very Good, Fairly good, Good, Indifferent, Bad, Fairly Bad, Very Bad, Vile\}

Using this approach, it comes down to a problem of optimisation using imprecise information and having two aims or criteria:

- good levels in the requirements needed for the demanded goods and

- good relationships among suppliers for related goods.

We will take in consideration these two criteria for designing the linguistic decision model.

Although we have described different term sets for each variable, in order to operate with their and taking into account that all of then have the same number of labels, only the first one will be considered. The others set of labels will be changed to this one from an operative point of view assuming a general label set. $L=\left\{l_{0}, l_{1}, \ldots, l_{8}\right\}$ and the corresponding transformation, for example $l_{3}$ is equivalent to $\operatorname{Bad}(R), \operatorname{Low}(L L)$ and Low $(W)$.

\section{LINGUISTIC SELECTION MODEL FOR SUPPLIERS SELECTION}

\subsection{Linguistic Aggregation}

In this subsection, we analyse two ways to aggregate linguistic information and two linguistic operators used in this paper.

Firstly, we are going to analyse the information to be aggregated in a linguistic process. Clearly, there are two types of linguistic information:

1. Non-weighted linguistic information. This is the situation in which we have only one set of linguistic values to aggregate.

2. Weighted linguistic information. This is the situation in which we have a set of linguistic values to aggregate, for example opinions and each value is characterised by an importance degree, indicating its weight in the overall set of values. 
In both cases, linguistic aggregation operators are needed that combine appropriately the information, in such a way, that the final aggregation is the "best" representation of the overall opinions. In the following subsections, we shall present the operators that we are going to consider in both cases.

\subsubsection{Non-weighted linguistic information}

In the literature various aggregation operators of linguistic information have been proposed. Some are based on the use of the associated membership functions of the labels [Bonissone and Decker, 1986; Tong, 1980], and others act by direct computation on labels [Delgado et al., 1993; Herrera and Verdegay, 1993; Yager 1992; Yager, 1995]. Here we will use the later approach. We consider two operators, the linguistic ordered weighted averaging (LOWA) operator presented in [Herrera and Verdegay, 1993] and the inverse-linguistic ordered weighted averaging (I-LOWA) operator presented in [Herrera and Herrera-Viedma, 1997].

Definition of the LOWA operator. Let $A=\left\{a_{1}, \ldots, a_{m}\right\}$ be a set of labels to be aggregated, then the LOWA operator, $\phi$, is defined as

$$
\begin{gathered}
\phi\left(a_{1}, \ldots, a_{m}\right)=W \cdot B^{T}=C^{m}\left\{w_{k}, b_{k}, k=1, \ldots, m\right\}= \\
=w_{1} \otimes b_{1} \oplus\left(1-w_{1}\right) \otimes C^{m-1}\left\{\beta_{h}, b_{h}, h=2, \ldots, m\right\}
\end{gathered}
$$

where $W=\left[w_{1}, \ldots, w_{m}\right]$, is a weighting vector, such that: $(i) w_{i} \in[0,1]$ and, (ii) $\sum w_{i}=1$.

$\beta_{h}=w_{h} / \sum_{2}^{m} w_{k}, h=2, \ldots, m$, and $B=\left\{b_{1}, \ldots, b_{m}\right\}$ is a vector associated to A, such that,

$$
B=\sigma(A)=\left\{a_{\sigma(1)}, \ldots, a_{\sigma(n)}\right\}
$$

where, $a_{\sigma(j)} \leq a_{\sigma(i)} \forall i \leq j$, with $\sigma$ being a permutation over the set of labels A. $C^{m}$ is the convex combination operator of $m$ labels, $\otimes$ is the general product of a label by a positive real number and $\oplus$ is the general addition of labels defined in [Delgado et al., 1993b].

If $m=2$, then $C^{2}$ is defined as $C^{2}\left\{w_{i}, b_{i,} i=1,2\right\}=w_{1} \otimes s_{j} \oplus\left(1-w_{1}\right) \otimes s_{i}=s_{k}, s_{j}, s_{i} \in S,(j \geq i)$ 
such that $k=\min \left\{T, i+\operatorname{round}\left(w_{1} \cdot(j-i)\right)\right\}$, where "round" is the usual round operation, and $b_{1}=s_{j}, b_{2}=s_{i}$.

If $w_{j}=1$ and $w_{i}=0$ with $i \neq j \forall i$, then the convex combination is defined as:

$$
C^{m}\left\{w_{i}, b_{i}, i=1, \ldots, m\right\}=b_{j}
$$

Definition of the I-LOWA operator. An I-LOWA (Inverse-Linguistic Ordered Weighted Averaging) operator, $\phi^{I}$, is a type of LOWA operator, in which

where, $a_{\sigma(i)} \leq a_{\sigma(j)} \quad \forall i \leq j$.

$$
B=\sigma^{I}(A)=\left\{a_{\sigma(1)}, \ldots a_{\sigma(n)}\right\}
$$

If $m=2$, then it is defined as

$$
C^{2}\left\{w_{i}, b_{i}, i=1,2\right\}=w_{1} \otimes s_{j} \oplus\left(1-w_{1}\right) \otimes s_{i}=s_{k}, s_{j}, s \in S,(j \leq i)
$$

such that $k=\min \left\{T, i+\operatorname{round}\left(w_{1} \cdot(j-i)\right)\right\}$.

The LOWA and I-LOWA operators are increasing monotonous, commutative, "around" operators, which verify the axioms: Unrestricted domain, Unanimity or Idempotence, Positive association of social and individual values, Independence of irrelevant alternatives, Citizen sovereignty, Neutrality [Herrera et al., 1996].

In the OWA operators the weights measure the importance of a value (in relation to other values) with independence of the information source. How to calculate the weighting vector of LOWA operator, $W$, is a basic question to be solved. A possible solution is that the weights represent the concept of fuzzy majority in the aggregation of LOWA operator using fuzzy linguistic quantifiers [Zadeh, 1983]. Yager proposed an interesting way to compute the weights of the OWA aggregation operator, which, in the case of a non-decreasing proportional fuzzy linguistic quantifier, $Q$, is given by this expression [Yager, 1988]:

$$
w_{i}=Q(i / n)-Q((i-1) / n), i=1, \ldots, n \text {; }
$$

being the membership function of $Q$, as follows:

$$
Q(r)= \begin{cases}0 & \text { if } r<a \\ \frac{r-a}{b-a} & \text { if } a \leq r \leq b \\ 1 & \text { if } r>b\end{cases}
$$

with $a, b, r \in[0,1]$. Some examples of non-decreasing proportional fuzzy linguistic quantifiers are: "most" $(0.3,0.8)$, "at least half" $(0,0.5)$ and "as many as possible" $(0.5,1)$. When a fuzzy linguistic quantifier, $Q$, is used to compute the 
weights of LOWA operator, $\phi$, it is symbolised by $\phi_{Q}$. Similarly happens for the I-LOWA operator, i.e., in this case it is symbolised by $\phi_{Q}^{I}$.

Some examples of proportional quantifiers are shown in Figure 4, where the parameters, $(\mathrm{a}, \mathrm{b})$ are $(0.3,0.8),(0,0.5)$ and $(0.5,1)$, respectively.
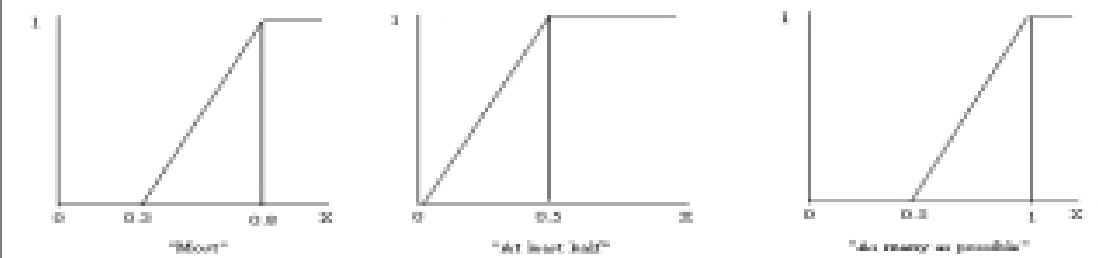

Figure 4

\subsubsection{Weighted linguistic information}

We may find situations where the handle information is not equally important, that is managing weighted information. In order to aggregate weighted information, we have to combine linguistic information with the weights, which involves the transformation of the weighted information under the importance degrees.

According to these ideas, the linguistic weighted aggregation (LWA) operator to aggregate linguistic weighted information is provided in [Herrera and Herrera-Viedma, 1997], which was defined using the LOWA operator [Herrera and Verdegay, 1993], the concept of fuzzy majority represented by a fuzzy linguistic quantifiers [Zadeh, 1983], and two families of linguistic connectives [Herrera and Herrera-Viedma, 1997]. In the following we review it.

Definition of the LWA operator. The aggregation of set of weighted individual opinions, $\left\{\left(c_{1}, a_{1}\right), \ldots,\left(c_{m}, a_{m}\right)\right\}$, according to the LWA operator is defined as

$$
\left(c_{E}, a_{E}\right)=L W A\left[\left(c_{1}, a_{1}\right), \ldots,\left(c_{m}, a_{m}\right)\right],
$$

where the importance degree of the opinion of the group, $c_{E}$, is obtained as

$$
c_{E}=\phi_{Q}\left(c_{1}, \ldots, c_{m}\right) \text {. }
$$


and, the opinion of the group, $a_{E}$, is obtained as

$$
a_{E}=f\left[g\left(c_{1}, a_{1}\right), \ldots, g\left(c_{m}, a_{m}\right)\right],
$$

where $f \in\left\{\phi_{Q}, \phi_{Q}^{I}\right\}$ is an linguistic aggregation operator of transformed information and $g$ is an importance transformation function, such that $g \in L C \rightarrow$ if $f=\phi_{Q}$ and $g \in L I^{\rightarrow}$ if $f=\phi_{Q}^{I}$, being $L C \rightarrow$ the following linguistic conjunction functions:

1. The classical MIN operator:

$$
L C_{1} \rightarrow(c, a)=\operatorname{MIN}(c, a)
$$

2. The nilpotent MIN operator:

$$
L C_{2} \rightarrow(c, a)= \begin{cases}\operatorname{MIN}(c, a) & \text { if } c>N e g(a) \\ 0 & \text { otherwise }\end{cases}
$$

3. The weakest conjunction:

$$
L C_{3} \rightarrow(c, a)= \begin{cases}\operatorname{MIN}(c, a) & \text { if } \operatorname{MAX}(c, a)=s_{T} \\ 0 & \text { otherwise }\end{cases}
$$

and $L I \rightarrow$ any of the following linguistic implication:

1. Kleene-Dienes's implication function:

$$
L I_{1} \rightarrow(c, a)=\operatorname{MIN}(c, a)
$$

2. Godel's implication function:

$$
L I_{2} \rightarrow(c, a)= \begin{cases}s_{t} & \text { if } c \leq a \\ a & \text { otherwise }\end{cases}
$$

3. Fodor's implication function:

$$
\mathrm{LI}_{3} \rightarrow(c, a)= \begin{cases}s_{t} & \text { if } c \leq a \\ \operatorname{MAX}(\operatorname{Neg}(c), a) & \text { otherwise }\end{cases}
$$

Where "MAX" stands for maximum operator and "MIN" stands for minimum operator.

It should be observed that LWA operator tries to reduce the effect of elements with low importance. In order to do so, when $f=\phi_{Q}$, the elements with low importance are transformed into small values and when $f=\phi_{Q}^{I}$ into large ones. 


\subsection{Selection Model}

Let $S=\left\{S_{1}, S_{2}, \ldots, S_{m}\right\}$, be a candidates for suppliers solution obtained in some way, where $S_{i} \in\{1,2, \ldots, N\}$.

For evaluating the solutions we propose a model that uses the information represented by linguistic labels, according with those aforementioned criteria, good levels in the requirements needed for the demanded goods and good relationships among suppliers for related goods. Therefore we obtain a bicriteria linguistic evaluation for every candidate for suppliers solution.

\section{Criterion 1. Good level in the requirements.}

- Step 1. First, to obtain a value of the supplier suitability on the requirements of a demanded $\operatorname{good}\left(S_{i}, G_{i}\right)$, we will apply an LWA operator as follows:

- Step 1.1. For each demanded good, $G_{i}$, there are $p$ requirements which define it, with $p$ degrees of importance for each requirement, $I R_{i j}$. Thus, to assess the suitability of the supplier $S_{i}$ for the demanded good a link must be established between the level that the person has of a given requirement and the weight assigned to that requirement for the demanded good. To achieve this, the proposal is to use the linguistic conjunction MIN that penalises solutions with suppliers with a low level in important requirements.

$$
g_{1}\left(I R_{i j}, L_{S_{i} j}\right)=L C_{1}^{\rightarrow}\left(I R_{i j}, L_{S_{i} j}\right), j=1, \ldots, p
$$

- Step 1.2. After that, to obtain a label representing the level of the supplier in the demanded good, we propose to use a LOWA with the "most" linguistic quantifier. Therefore the final label is:

$$
\begin{aligned}
& Y_{S_{i}}=f\left(g_{1}\left(I R_{i 1}, L_{S_{i} 1}\right), \ldots, g_{1}\left(I R_{i m 2}, L_{S_{i} p}\right)\right)= \\
& =\phi_{Q}\left(g_{1}\left(I R_{i 1}, L_{S_{i} 1}\right), \ldots, g_{1}\left(I R_{i p}, L_{S_{i} p}\right)\right)
\end{aligned}
$$

- Step 2. Second, to obtain a value of the solution suitability on the requirements of all the demanded goods, we will apply again an LWA operator as follows:

- Step 2.1. By taking the steps outlined above, it is possible to obtain a linguistic label setting a value on the ability of each supplier relative to each demanded good. However, the intention is to give an overall value covering the suitability of suppliers to demanded goods that will include the fact that the various demanded goods are themselves of different levels of importance. In view of this, it is proposed to use again a classical conjunction MIN, so that the solution as to suitability for demanded goods may be obtained in the form of a linguistic label.

$$
g_{2}\left(I G_{i}, Y_{S_{i}}\right)=L C_{1}^{\rightarrow}\left(I G_{i}, Y_{S_{i}}\right), i=1, \ldots, m
$$


- Step 2.2. Thus, to obtain a label representing the level of the overall solution, we propose to use a LOWA with the "most" linguistic quantifier.

$$
\begin{aligned}
& Y_{s}=f\left(g_{2}\left(I G_{1}, Y_{S_{1}}\right), \ldots, g_{2}\left(I G_{m}, Y_{S_{m}}\right)\right)= \\
& =\phi_{Q}\left(g_{2}\left(I G_{1}, Y_{S_{1}}\right), \ldots, g_{2}\left(I G_{m}, Y_{S_{m}}\right)\right)
\end{aligned}
$$

With these steps, we have obtained a linguistic evaluation of the candidates for suppliers in the requirements of the demanded good. Nevertheless, the goodness of the solutions will also be determined by the relationships between the suppliers included in them. On the one hand, the connections between demanded goods are known, as is the weighting for each, and on the other the relationships among suppliers are known.

\section{Criterion 2. Good relationship among the suppliers selected.}

- Step 3. First, to obtain a value of the suppliers relationships of each demanded good, $X^{\prime}{ }_{i}$, we will apply a LWA operator as follows:

- Step 3.1. So, a link is established for each demanded good between the weighting of its connections to other demanded goods and the degree of relationship that the supplier selected to the demanded good has with suppliers selected for related demanded goods. To achieve this, the proposed method would be to use the "Keene and Diene" Linguistic Implication.

$$
g_{3}\left(R G_{i j}, R S_{S_{i} S_{j}}\right)=L I_{1} \rightarrow\left(R G_{i j}, R S_{S_{i} S_{j}}\right), i=1, \ldots, m
$$

- Step 3.2. To obtain a label representing the relationship of the suppliers selected of each demanded good, $X_{i}^{\prime}$, we propose to use an I-LOWA operator with the "most" quantifier.

$$
\begin{aligned}
& V_{i}=f\left(g_{3}\left(R G_{i 1}, R S_{S_{i} S_{1}}\right), \ldots, g_{3}\left(R G_{i m}, R S_{S_{i} S_{m}}\right)\right)= \\
& =\phi_{Q}^{I}\left(g_{3}\left(R P_{i 1}, R C_{S_{i} S_{1}}\right), \ldots, g_{3}\left(R P_{i m}, R C_{S_{i} S_{m}}\right)\right)
\end{aligned}
$$

- Step 4. Once this has been done, to set a value of the relationship to the overall solution, the proposal is to use an LOWA operator with the "most" quantifier.

$$
V_{S}=f\left(V_{1}, \ldots, V_{m}\right)=\phi_{Q}\left(V_{1}, \ldots, V_{m}\right)
$$

With the last three steps, we have obtained a linguistic evaluation of the relationship among the suppliers selected in the solution.

Finally, we have obtained two linguistic labels $\left(Y_{s}, V_{s}\right)$, that are the evaluation for each feasible solution, $S$, according to the two objectives of the problem: the level of the suppliers selected on each demanded good and the relationship among them. 


\section{EXAMPLE OF A PRACTICAL APPLICATION}

To check the working of the decision method, an operational model was developed. Several examples were tried out, including the one described below. This deals with the choice of suppliers for a wheel of a car factory. In this way, an attempt was made to demonstrate the usefulness the model being proposed in this paper could have for real problems from the business world.

\subsection{Introduction to the problem. Linguistic Model}

Let it be imagined that a car factory wishes to purchase the goods necessary to manufacture a wheel. The first step is to determine which goods are to be acquired, what status in terms of urgency each is to have in relation to the purchase process and what monetary quantity is expecting to be purchased (monetary units). Thus, we might have:

Demanded Good Status (IG)

$\begin{array}{lll}1 & \text { SCREW } & \text { High } \\ 2 & \text { NUT } & \text { Fairly High } \\ 3 & \text { TYRE } & \text { Moderate } \\ 4 & \text { RIM } & \text { Low } \\ 5 & \text { HUB-CAB } & \text { Very Low }\end{array}$

For each good, the requirements which must be developed and the weighting that each has for the supply in question are known, as is shown in Chart 1:

\begin{tabular}{|l|c|c|c|c|c|}
\hline \multicolumn{1}{|c|}{$I R_{j i}$} & SCREW & NUT & TYRE & $R I M$ & HUB-CAB \\
\hline $\begin{array}{l}\text { Technical } \\
\text { Ability }\end{array}$ & Essential & - & - & - & - \\
\hline $\begin{array}{l}\text { Technological } \\
\text { Innovation }\end{array}$ & Fairly High & - & - & - & - \\
\hline $\begin{array}{l}\text { Manufacturing } \\
\text { Capacity }\end{array}$ & Fairly High & Moderate & Fairly High & Moderate & Very High \\
\hline Fast Supply & High & - & - & - & - \\
\hline $\begin{array}{l}\text { Reciprocal } \\
\text { Business }\end{array}$ & Moderate & - & - & - & - \\
\hline Standardisation & - & Low & - & Fairly High & - \\
\hline Reliability & - & High & - & Fairly High & - \\
\hline $\begin{array}{l}\text { After Sales } \\
\text { Service }\end{array}$ & - & Fairly High & - & Low & Fairly High \\
\hline $\begin{array}{l}\text { Supplier } \\
\text { Location }\end{array}$ & - & Very high & Fairly Low & - & - \\
\hline $\begin{array}{l}\text { Financially } \\
\text { Strong }\end{array}$ & - & - & Moderate & - & Moderate \\
\hline Flexibility & - & - & High & - & Very High \\
\hline Credit Terms & - & - & Very High & - & Very Low \\
\hline Quality & - & - & - & High & - \\
\hline
\end{tabular}

Chart 1 
In addition, the last piece of information needed in setting up these demanded goods would be the required compatibility between each supplier and the others and the importance set on such relationships, as is shown in Chart 2.

\begin{tabular}{|l|c|c|c|c|c|}
\hline \multicolumn{1}{|c|}{$R G$} & $G O O D$ 1 & $G O O D 2$ & $G O O D$ 3 & $G O O D$ 4 & GOOD 5 \\
\hline$G O O D 1$ & - & Fairly High & High & Moderate & Fairly Low \\
\hline GOOD 2 & Fairly High & - & Moderate & Moderate & Low \\
\hline GOOD 3 & Low & Very High & - & Very High & High \\
\hline GOOD 4 & Low & Moderate & Very High & - & Very High \\
\hline GOOD 5 & Fairly Low & Moderate & Fairly High & Very High & - \\
\hline
\end{tabular}

\section{Chart 2}

Once the demanded goods involved in the selection procedure have been determined, the candidates for suppliers must next be considered. Let it be imagined that there are fifteen companies who might be able to provide the goods necessaries for the wheel.

\begin{tabular}{cll} 
Company & Name & Good Supplied \\
\hline 1 & S.1 & NUT \\
2 & $S .2$ & SCREW \\
3 & $S .3$ & TYRE \\
4 & $S .4$ & HUB-CAB \\
5 & $S .5$ & RIM \\
6 & $S .6$ & HUB-CAB \\
7 & $S .7$ & RIM \\
8 & $S .8$ & TYRE \\
9 & $S .9$ & NUT \\
10 & $S .10$ & SCREW \\
11 & $S .11$ & HUB-CAB \\
12 & $S .12$ & RIM \\
13 & $S .13$ & TYRE \\
14 & $S .14$ & NUT \\
15 & $S .15$ & SCREW
\end{tabular}

For each one it is necessary to find out by some appropriate means the levels in each of the requirements required for the supplies, as shown in Chart 3.

Finally, as there are links between the goods, the candidates for suppliers must be looked at in order to find out the relationships that there would be between them, as shown in Chart 4 . 


\begin{tabular}{|c|c|c|c|c|c|c|c|c|c|c|c|c|c|c|c|}
\hline$L$ & $\begin{array}{l}\text { S. } 1 \\
\end{array}$ & S. 2 & S. 3 & S. 4 & S. 5 & S. 6 & S. 7 & S. 8 & S. 9 & S. 10 & S. 11 & S. 12 & S. 13 & S. 14 & S. 15 \\
\hline $\begin{array}{l}\text { Technical } \\
\text { Ability }\end{array}$ & $\begin{array}{l}\text { Very } \\
\text { High }\end{array}$ & $\begin{array}{l}\text { Very } \\
\text { high }\end{array}$ & Low & High & High & High & $\begin{array}{l}\text { Fairly } \\
\text { High }\end{array}$ & $\begin{array}{l}\text { Very } \\
\text { High }\end{array}$ & $\begin{array}{l}\text { Very } \\
\text { High }\end{array}$ & $\begin{array}{l}\text { Very } \\
\text { High }\end{array}$ & $\begin{array}{l}\text { Fairly } \\
\text { High }\end{array}$ & High & High & $\begin{array}{l}\text { Mode- } \\
\text { rate }\end{array}$ & $\begin{array}{c}\text { Mode- } \\
\text { rate }\end{array}$ \\
\hline $\begin{array}{l}\text { Technological } \\
\text { Innovation }\end{array}$ & $\begin{array}{c}\text { Fairly } \\
\text { High }\end{array}$ & $\begin{array}{c}\text { Fairly } \\
\text { High }\end{array}$ & $\begin{array}{c}\text { Mode- } \\
\text { rate }\end{array}$ & $\begin{array}{l}\text { Fairly } \\
\text { High }\end{array}$ & $\begin{array}{l}\text { Fairly } \\
\text { High }\end{array}$ & $\begin{array}{c}\text { Mode- } \\
\text { rate }\end{array}$ & $\begin{array}{c}\text { Mode- } \\
\text { rate }\end{array}$ & High & $\begin{array}{l}\text { Fairly } \\
\text { High }\end{array}$ & \begin{tabular}{|l|} 
Fairly \\
High \\
\end{tabular} & Low & High & High & $\begin{array}{c}\text { Fairly } \\
\text { High }\end{array}$ & $\begin{array}{c}\text { Fairly } \\
\text { High }\end{array}$ \\
\hline $\begin{array}{l}\text { Manufacturing } \\
\text { Capacity }\end{array}$ & $\begin{array}{c}\text { Mode- } \\
\text { rate }\end{array}$ & $\begin{array}{l}\text { Fairly } \\
\text { High }\end{array}$ & $\begin{array}{c}\text { Mode- } \\
\text { rate }\end{array}$ & $\begin{array}{l}\begin{array}{l}\text { Fairly } \\
\text { Low }\end{array} \\
\end{array}$ & Low & High & $\begin{array}{c}\text { Mode- } \\
\text { rate }\end{array}$ & $\begin{array}{l}\text { Fairly } \\
\text { High }\end{array}$ & $\begin{array}{c}\text { Mode- } \\
\text { rate }\end{array}$ & High & $\begin{array}{l}\text { Fairly } \\
\text { High }\end{array}$ & High & \begin{tabular}{c|} 
Fairly \\
High
\end{tabular} & $\begin{array}{c}\text { Mode- } \\
\text { rate }\end{array}$ & High \\
\hline Quality & High & High & $\begin{array}{c}\text { Fairly } \\
\text { Low }\end{array}$ & Low & $\begin{array}{l}\text { Fairly } \\
\text { High }\end{array}$ & Low & Low & $\begin{array}{c}\text { Mode- } \\
\text { rate }\end{array}$ & High & High & $\begin{array}{l}\text { Fairly } \\
\text { Low }\end{array}$ & $\begin{array}{l}\text { Fairly } \\
\text { High }\end{array}$ & $\begin{array}{c}\text { Mode- } \\
\text { rate }\end{array}$ & High & $\begin{array}{c}\text { Mode- } \\
\text { rate }\end{array}$ \\
\hline Standardisation & High & High & Low & $\begin{array}{l}\text { Mode- } \\
\text { rate }\end{array}$ & $\begin{array}{l}\text { Fairly } \\
\text { Low }\end{array}$ & $\begin{array}{l}\text { Fairly } \\
\text { High }\end{array}$ & $\begin{array}{c}\begin{array}{c}\text { Mode- } \\
\text { rate }\end{array} \\
\end{array}$ & $\begin{array}{l}\text { Fairly } \\
\text { High }\end{array}$ & High & High & $\begin{array}{l}\text { Very } \\
\text { High }\end{array}$ & Low & $\begin{array}{l}\text { Mode- } \\
\text { rate }\end{array}$ & $\begin{array}{l}\text { Fairly } \\
\text { High }\end{array}$ & High \\
\hline Rel & $\begin{array}{l}\text { Very } \\
\text { Low }\end{array}$ & $\begin{array}{l}\text { Mode- } \\
\text { rate }\end{array}$ & $\begin{array}{c}\text { Mode- } \\
\text { rate }\end{array}$ & $\begin{array}{l}\text { Fairly } \\
\text { Low }\end{array}$ & Lowest & High & $\begin{array}{l}\text { Fairly } \\
\text { Low }\end{array}$ & Lowest & $\begin{array}{l}\text { Very } \\
\text { High }\end{array}$ & \begin{tabular}{|c|}
$\begin{array}{c}\text { Mode- } \\
\text { rate }\end{array}$ \\
\end{tabular} & $\begin{array}{l}\text { Mode- } \\
\text { rate }\end{array}$ & $\begin{array}{l}\text { Mode- } \\
\text { rate }\end{array}$ & Lowest & $\begin{array}{l}\text { Very } \\
\text { High }\end{array}$ & $\begin{array}{l}\text { Mode- } \\
\text { rate }\end{array}$ \\
\hline $\begin{array}{l}\text { Financially } \\
\text { Strong }\end{array}$ & $\begin{array}{c}\text { Fairly } \\
\text { High } \\
\end{array}$ & $\begin{array}{l}\text { Fairly } \\
\text { High }\end{array}$ & Low & High & $\begin{array}{l}\text { Mode- } \\
\text { rate }\end{array}$ & $\begin{array}{l}\text { Fairly } \\
\text { High } \\
\end{array}$ & High & $\begin{array}{l}\text { Very } \\
\text { High } \\
\end{array}$ & $\begin{array}{l}\text { Fairly } \\
\text { High }\end{array}$ & \begin{tabular}{|c|} 
Fairly \\
High \\
\end{tabular} & $\begin{array}{l}\text { Very } \\
\text { High } \\
\end{array}$ & $\begin{array}{c}\text { Mode- } \\
\text { rate }\end{array}$ & $\begin{array}{l}\text { Very } \\
\text { High }\end{array}$ & $\begin{array}{c}\text { Fairly } \\
\text { High } \\
\end{array}$ & $\begin{array}{c}\text { Mode- } \\
\text { rate }\end{array}$ \\
\hline $\begin{array}{l}\text { After-Sales } \\
\text { Service }\end{array}$ & $\begin{array}{l}\text { Very } \\
\text { High }\end{array}$ & $\begin{array}{l}\text { Very } \\
\text { High }\end{array}$ & $\begin{array}{c}\text { Mode- } \\
\text { rate }\end{array}$ & High & $\begin{array}{l}\text { Fairly } \\
\text { Low }\end{array}$ & $\begin{array}{l}\text { Very } \\
\text { High }\end{array}$ & $\begin{array}{c}\text { Fairly } \\
\text { High }\end{array}$ & $\begin{array}{l}\text { Fairly } \\
\text { High }\end{array}$ & $\begin{array}{l}\text { Very } \\
\text { High }\end{array}$ & $\begin{array}{l}\text { Very } \\
\text { High }\end{array}$ & $\begin{array}{l}\text { Fairly } \\
\text { High }\end{array}$ & Low & High & $\begin{array}{l}\text { Very } \\
\text { High }\end{array}$ & $\begin{array}{l}\text { Very } \\
\text { High }\end{array}$ \\
\hline Flexibility & High & High & Low & $\begin{array}{c}\text { Mode- } \\
\text { rate }\end{array}$ & $\begin{array}{l}\text { Very } \\
\text { Low }\end{array}$ & $\begin{array}{l}\text { Fairly } \\
\text { High } \\
\end{array}$ & High & Low & High & High & High & $\begin{array}{c}\text { Mode- } \\
\text { rate }\end{array}$ & Low & High & $\begin{array}{c}\text { Mode- } \\
\text { rate }\end{array}$ \\
\hline $\begin{array}{l}\text { Supplier } \\
\text { Location }\end{array}$ & High & High & $\begin{array}{l}\text { Mode- } \\
\text { rate }\end{array}$ & $\begin{array}{l}\text { Fairly } \\
\text { High }\end{array}$ & Low & $\begin{array}{l}\text { Fairly } \\
\text { High }\end{array}$ & Low & $\begin{array}{l}\text { Fairly } \\
\text { High }\end{array}$ & High & High & High & $\begin{array}{c}\text { Mode- } \\
\text { rate }\end{array}$ & $\begin{array}{l}\text { Fairly } \\
\text { High }\end{array}$ & High & High \\
\hline Fast supply & Low & $\begin{array}{l}\text { Fairly } \\
\text { High }\end{array}$ & $\begin{array}{l}\text { Mode- } \\
\text { rate }\end{array}$ & $\begin{array}{l}\text { Mode- } \\
\text { rate }\end{array}$ & $\begin{array}{l}\text { Very } \\
\text { Low }\end{array}$ & $\begin{array}{c}\text { Mode } \\
\text {-rate }\end{array}$ & Low & $\begin{array}{l}\text { Fairly } \\
\text { Low }\end{array}$ & Low & $\begin{array}{l}\text { Fairly } \\
\text { High }\end{array}$ & Low & Low & $\begin{array}{c}\text { Mode- } \\
\text { rate }\end{array}$ & Low & $\begin{array}{c}\text { Mode- } \\
\text { rate }\end{array}$ \\
\hline Credit terms & $\begin{array}{l}\text { Fairly } \\
\text { High } \\
\end{array}$ & $\begin{array}{l}\text { Fairly } \\
\text { High } \\
\end{array}$ & Low & High & Lowest & High & $\begin{array}{c}\text { Fairly } \\
\text { Low }\end{array}$ & $\begin{array}{l}\text { Very } \\
\text { High } \\
\end{array}$ & $\begin{array}{l}\text { Fairly } \\
\text { High } \\
\end{array}$ & \begin{tabular}{|c|} 
Fairly \\
High \\
\end{tabular} & $\begin{array}{l}\text { Fairly } \\
\text { High } \\
\end{array}$ & $\begin{array}{c}\text { Fairly } \\
\text { Low }\end{array}$ & $\begin{array}{l}\text { Very } \\
\text { High } \\
\end{array}$ & $\begin{array}{l}\text { Fairly } \\
\text { High } \\
\end{array}$ & $\begin{array}{c}\text { Fairly } \\
\text { High } \\
\end{array}$ \\
\hline $\begin{array}{l}\text { Reciprocal } \\
\text { Business }\end{array}$ & $\begin{array}{l}\text { Very } \\
\text { Low }\end{array}$ & $\begin{array}{l}\text { Mode- } \\
\text { rate }\end{array}$ & $\begin{array}{l}\text { Mode- } \\
\text { rate }\end{array}$ & $\begin{array}{l}\text { Fairly } \\
\text { Low }\end{array}$ & Lowest & $\begin{array}{l}\text { Fairly } \\
\text { High }\end{array}$ & Low & Lowest & $\begin{array}{l}\text { Very } \\
\text { High }\end{array}$ & \begin{tabular}{|c|}
$\begin{array}{c}\text { Mode- } \\
\text { rate }\end{array}$ \\
\end{tabular} & High & $\begin{array}{l}\text { Mode- } \\
\text { rate }\end{array}$ & Lowest & $\begin{array}{l}\text { Fairly } \\
\text { High }\end{array}$ & $\begin{array}{l}\text { Mode- } \\
\text { rate }\end{array}$ \\
\hline
\end{tabular}

Chart 3 


\begin{tabular}{|c|c|c|c|c|c|c|c|c|c|c|c|c|c|c|c|}
\hline$R S$ & $\mathrm{C} 1$ & $\mathrm{C} 2$ & C 3 & $\mathrm{C} 4$ & $\mathrm{C} 5$ & $\mathrm{C} 6$ & C 7 & C 8 & C 9 & C 10 & C 11 & C 12 & C 13 & C 14 & C 15 \\
\hline C 1 & - & $\begin{array}{l}\text { Very } \\
\text { Good } \\
\end{array}$ & Bad & Good & $\begin{array}{c}\text { Indiffe- } \\
\text { rent }\end{array}$ & Very Bad & $\begin{array}{c}\text { Indiffe- } \\
\text { rent }\end{array}$ & Very Bad & Vile & $\begin{array}{l}\text { Very } \\
\text { Good } \\
\end{array}$ & Bad & Good & $\begin{array}{c}\text { Indiffe- } \\
\text { rent }\end{array}$ & \begin{tabular}{|c|} 
Fairly \\
Bad
\end{tabular} & $\begin{array}{c}\text { Indiffe- } \\
\text { rent }\end{array}$ \\
\hline C 2 & \begin{tabular}{|c|} 
Fairly \\
Bad
\end{tabular} & - & $\mathrm{Bad}$ & $\begin{array}{c}\text { Indiffe- } \\
\text { rent }\end{array}$ & $\begin{array}{c}\text { Indiffe- } \\
\text { rent }\end{array}$ & Good & $\begin{array}{c}\text { Indiffe- } \\
\text { rent }\end{array}$ & Fairly Bad & Good & $\begin{array}{l}\text { Very } \\
\text { Good }\end{array}$ & $\mathrm{Bad}$ & Good & $\begin{array}{c}\text { Indiffe- } \\
\text { rent }\end{array}$ & \begin{tabular}{|c|} 
Fairly \\
Bad
\end{tabular} & $\begin{array}{c}\text { Indiffe- } \\
\text { rent }\end{array}$ \\
\hline C 3 & $\begin{array}{c}\text { Very } \\
\text { Good }\end{array}$ & $\begin{array}{l}\text { Fairly } \\
\text { Good }\end{array}$ & - & $\mathrm{Bad}$ & Good & $\begin{array}{c}\text { Indiffe- } \\
\text { rent }\end{array}$ & Good & Vile & $\begin{array}{l}\text { Very } \\
\text { Good }\end{array}$ & $\begin{array}{l}\text { Very } \\
\text { Good }\end{array}$ & $\mathrm{Bad}$ & Good & $\begin{array}{c}\text { Indiffe- } \\
\text { rent }\end{array}$ & $\begin{array}{c}\text { Fairly } \\
\text { Bad }\end{array}$ & $\begin{array}{c}\begin{array}{c}\text { Indiffe- } \\
\text { rent }\end{array} \\
\end{array}$ \\
\hline $\mathrm{C} 4$ & $\begin{array}{c}\text { Fairly } \\
\text { Bad }\end{array}$ & Good & $\begin{array}{c}\text { Indiffe- } \\
\text { rent }\end{array}$ & - & $\mathrm{Bad}$ & Good & $\begin{array}{c}\text { Indiffe- } \\
\text { rent }\end{array}$ & $\begin{array}{c}\text { Indiffe- } \\
\text { rent }\end{array}$ & $\begin{array}{c}\text { Fairly } \\
\text { Bad }\end{array}$ & $\begin{array}{l}\text { Very } \\
\text { Good }\end{array}$ & $\mathrm{Bad}$ & Good & $\begin{array}{c}\text { Indiffe- } \\
\text { rent }\end{array}$ & \begin{tabular}{|c} 
Fairly \\
Bad
\end{tabular} & $\begin{array}{c}\text { Indiffe- } \\
\text { rent }\end{array}$ \\
\hline C 5 & $\begin{array}{l}\text { Very } \\
\text { Good }\end{array}$ & Good & Good & Bad & - & Good & Fairly Bad & Fairly Bad & Vile & $\begin{array}{l}\text { Very } \\
\text { Good }\end{array}$ & Bad & Good & $\begin{array}{c}\text { Indiffe- } \\
\text { rent }\end{array}$ & $\begin{array}{c}\text { Fairly } \\
\text { Bad }\end{array}$ & $\begin{array}{c}\begin{array}{c}\text { Indiffe- } \\
\text { rent }\end{array} \\
\text {. }\end{array}$ \\
\hline C 6 & \begin{tabular}{|c|} 
Very \\
Good
\end{tabular} & Good & $\begin{array}{c}\text { Indiffe- } \\
\text { rent }\end{array}$ & $\mathrm{Bad}$ & Good & - & $\begin{array}{c}\text { Indiffe- } \\
\text { rent }\end{array}$ & $\mathrm{Bad}$ & Good & $\begin{array}{l}\text { Very } \\
\text { Good }\end{array}$ & $\mathrm{Bad}$ & Good & $\begin{array}{c}\text { Indiffe- } \\
\text { rent }\end{array}$ & \begin{tabular}{|c} 
Fairly \\
Bad
\end{tabular} & $\begin{array}{c}\begin{array}{c}\text { Indiffe- } \\
\text { rent }\end{array} \\
\end{array}$ \\
\hline C7 & $\mathrm{Bad}$ & Good & Good & $\begin{array}{l}\text { Fairly } \\
\text { Good }\end{array}$ & $\begin{array}{l}\text { Very } \\
\text { Good } \\
\end{array}$ & $\begin{array}{l}\text { Fairly } \\
\text { Good }\end{array}$ & - & Very Bad & Fairly Bad & $\begin{array}{l}\text { Very } \\
\text { Good }\end{array}$ & $\mathrm{Bad}$ & Good & $\begin{array}{c}\text { Indiffe- } \\
\text { rent }\end{array}$ & \begin{tabular}{|c|} 
Fairly \\
Bad \\
\end{tabular} & $\begin{array}{c}\begin{array}{c}\text { Indiffe- } \\
\text { rent }\end{array} \\
\end{array}$ \\
\hline C 8 & $\mathrm{Bad}$ & $\begin{array}{l}\text { Fairly } \\
\text { Good }\end{array}$ & Good & $\begin{array}{l}\text { Very } \\
\text { Good } \\
\end{array}$ & $\begin{array}{c}\text { Indiffe- } \\
\text { rent }\end{array}$ & $\begin{array}{l}\text { Fairly } \\
\text { Good }\end{array}$ & $\begin{array}{c}\text { Indiffe- } \\
\text { rent }\end{array}$ & - & $\begin{array}{c}\text { Fairly } \\
\text { Bad }\end{array}$ & $\begin{array}{l}\text { Very } \\
\text { Good } \\
\end{array}$ & $\mathrm{Bad}$ & Good & $\begin{array}{c}\text { Indiffe- } \\
\text { rent }\end{array}$ & \begin{tabular}{|c|} 
Fairly \\
Bad \\
\end{tabular} & $\begin{array}{c}\text { Indiffe- } \\
\text { rent }\end{array}$ \\
\hline C 9 & Vile & $\begin{array}{l}\text { Very } \\
\text { Good }\end{array}$ & $\mathrm{Bad}$ & Good & $\begin{array}{c}\text { Indiffe- } \\
\text { rent }\end{array}$ & airly Bad & $\begin{array}{c}\text { Indiffe- } \\
\text { rent }\end{array}$ & Very Bad & - & $\begin{array}{l}\text { Very } \\
\text { Good }\end{array}$ & $\mathrm{Bad}$ & Good & $\begin{array}{c}\text { Indiffe- } \\
\text { rent }\end{array}$ & \begin{tabular}{|c} 
Fairly \\
Bad
\end{tabular} & $\begin{array}{c}\text { Indiffe- } \\
\text { rent }\end{array}$ \\
\hline C 10 & $\begin{array}{c}\text { Fairly } \\
\text { Bad }\end{array}$ & $\begin{array}{l}\text { Very } \\
\text { Good }\end{array}$ & $\mathrm{Bad}$ & $\begin{array}{c}\text { Indiffe- } \\
\text { rent }\end{array}$ & $\begin{array}{c}\text { Indiffe- } \\
\text { rent }\end{array}$ & Good & $\begin{array}{c}\text { Indiffe- } \\
\text { rent }\end{array}$ & Fairly Bad & Good & - & $\mathrm{Bad}$ & Good & $\begin{array}{c}\text { Indiffe- } \\
\text { rent }\end{array}$ & $\begin{array}{c}\text { Fairly } \\
\text { Bad }\end{array}$ & $\begin{array}{c}\text { Indiffe- } \\
\text { rent }\end{array}$ \\
\hline C 11 & $\begin{array}{c}\text { Indiffe- } \\
\text { rent }\end{array}$ & Good & $\begin{array}{c}\text { Indiffe- } \\
\text { rent }\end{array}$ & Good & $\begin{array}{c}\text { Fairly } \\
\text { Good }\end{array}$ & $\begin{array}{l}\text { Fairly } \\
\text { Good }\end{array}$ & Bad & $\begin{array}{c}\text { Indiffe- } \\
\text { rent }\end{array}$ & $\begin{array}{l}\text { Fairly } \\
\text { Good }\end{array}$ & $\begin{array}{l}\text { Fairly } \\
\text { Good }\end{array}$ & - & $\begin{array}{c}\text { Indiffe- } \\
\text { rent }\end{array}$ & $\begin{array}{l}\text { Fairly } \\
\text { Good }\end{array}$ & $\begin{array}{c}\text { Indiffe- } \\
\text { rent }\end{array}$ & Very Bad \\
\hline C 12 & $\begin{array}{l}\text { Fairly } \\
\text { Good }\end{array}$ & Fairly Bad & $\mathrm{Bad}$ & Good & Good & Good & Very Bad & $\begin{array}{c}\text { Indiffe- } \\
\text { rent }\end{array}$ & $\begin{array}{c}\text { Indiffe- } \\
\text { rent }\end{array}$ & $\begin{array}{l}\text { Fairly } \\
\text { Good }\end{array}$ & $\begin{array}{c}\text { Indiffe- } \\
\text { rent }\end{array}$ & - & $\mathrm{Bad}$ & $\begin{array}{l}\text { Indiffe- } \\
\text { rent }\end{array}$ & $\mathrm{Bad}$ \\
\hline C 13 & $\begin{array}{c}\text { Indiffe- } \\
\text { rent }\end{array}$ & $\begin{array}{c}\text { Indiffe- } \\
\text { rent }\end{array}$ & $\begin{array}{c}\text { Indiffe- } \\
\text { rent }\end{array}$ & $\begin{array}{l}\text { Very } \\
\text { Good }\end{array}$ & $\begin{array}{c}\text { Indiffe- } \\
\text { rent }\end{array}$ & $\begin{array}{c}\text { Indiffe- } \\
\text { rent }\end{array}$ & Fairly Bad & $\mathrm{Bad}$ & $\begin{array}{c}\text { Fairly } \\
\text { Bad }\end{array}$ & \begin{tabular}{|l|} 
Very Bad \\
\end{tabular} & $\mathrm{Bad}$ & Very Bad & - & $\begin{array}{c}\text { Fairly } \\
\text { bad }\end{array}$ & Very Bad \\
\hline C 14 & $\begin{array}{l}\text { Fairly } \\
\text { Good }\end{array}$ & $\begin{array}{l}\text { Very } \\
\text { Good }\end{array}$ & $\begin{array}{l}\text { Fairly } \\
\text { Good }\end{array}$ & Good & $\begin{array}{c}\text { Indiffe- } \\
\text { rent }\end{array}$ & Good & $\begin{array}{c}\text { Indiffe- } \\
\text { rent }\end{array}$ & $\begin{array}{l}\text { Fairly } \\
\text { Good }\end{array}$ & Good & $\begin{array}{l}\text { Very } \\
\text { Good }\end{array}$ & $\begin{array}{l}\text { Fairly } \\
\text { Good }\end{array}$ & Good & $\begin{array}{c}\text { Indiffe- } \\
\text { rent }\end{array}$ & - & $\begin{array}{l}\text { Fairly } \\
\text { Good }\end{array}$ \\
\hline C 15 & $\begin{array}{c}\text { Indiffe- } \\
\text { rent }\end{array}$ & $\begin{array}{l}\text { Fairly } \\
\text { Good }\end{array}$ & $\mathrm{Bad}$ & $\begin{array}{c}\text { Indiffe- } \\
\text { rent }\end{array}$ & $\begin{array}{c}\text { Indiffe- } \\
\text { rent }\end{array}$ & Good & $\begin{array}{c}\text { Indiffe- } \\
\text { rent }\end{array}$ & Fairly Bad & Good & $\begin{array}{c}\text { Indiffe- } \\
\text { rent }\end{array}$ & $\mathrm{Bad}$ & Good & $\begin{array}{c}\text { Indiffe- } \\
\text { rent }\end{array}$ & $\begin{array}{c}\text { Fairly } \\
\text { Bad }\end{array}$ & - \\
\hline
\end{tabular}

Chart 4 


\subsection{Linguistic decision model}

Let $S=\{S .2, S .1, S .3, S .5, S .4\}$ be a possible solution. We are going to apply the decision model on it for obtaining the linguistic evaluation associated to the criteria.

\section{Criterion 1. Good level in the requirements.}

- $\quad$ Step 1.1.

\begin{tabular}{|c|c|c|c|c|c|}
\hline Good 1 & Tech. Ability & Tech. Imnov. & Manuf. Capac. & Fast Supply & Recip. Business \\
\hline$I R_{i j}$ & Essential & Fairly High & Fairly High & High & Moderate \\
\hline$L_{S_{i} j}$ & Very High & Fairly High & Moderate & Low & Very Low \\
\hline$L C_{1} \rightarrow$ & Very High & Fairly High & Moderate & Low & Very Low \\
\hline
\end{tabular}

\begin{tabular}{|c|c|c|c|c|c|}
\hline Good 2 & Manuf. Capac. & Standardisation & Reliability & After Sales Ser, & Supplier Loc. \\
\hline$I R_{i j}$ & Moderate & Low & High & Very High & Very High \\
\hline$L_{S_{i} j}$ & Fairly High & High & Moderate & Very High & High \\
\hline$L C_{1} \rightarrow$ & Moderate & Low & Moderate & Very High & High \\
\hline
\end{tabular}

\begin{tabular}{|c|c|c|c|c|c|}
\hline Good 3 & Manuf. Capac. & Supplier Loc. & Financ. Strong & Flexibility & Credit Terms \\
\hline$I R_{i j}$ & Fairly High & Fairly High & Moderate & High & Very High \\
\hline$L_{S_{i} j}$ & Moderate & Moderate & Low & Low & Low \\
\hline$L C_{1}^{\rightarrow}$ & Moderate & Moderate & Low & Low & Low \\
\hline
\end{tabular}

\begin{tabular}{|c|c|c|c|c|c|}
\hline Good 4 & Manuf. Capac. & Standardisation & Reliability & After Sales Ser. & Quality \\
\hline$I R_{i j}$ & Moderate & Fairly High & Fairly High & Low & High \\
\hline$L_{S_{i} j}$ & Low & Fairly Low & Lowest & Fairly Low & High \\
\hline$L C_{1} \rightarrow$ & Low & Fairly Low & Lowest & Fairly Low & High \\
\hline
\end{tabular}

\begin{tabular}{|c|c|c|c|c|c|}
\hline Good 5 & Manuf. Capac. & After Sales Ser. & Finac. Strong & Flexibility & Credit Terms \\
\hline$I R_{i j}$ & Very High & Fairly High & Moderate & Very High & Very Low \\
\hline$L_{S_{i} j}$ & Fairly Low & High & High & Moderate & High \\
\hline$L C_{1} \rightarrow$ & Fairly Low & High & Moderate & Moderate & Very Low \\
\hline
\end{tabular}

- $\quad$ Step 1.2.

$$
\begin{gathered}
Y_{S_{1}}=\phi_{Q}(V H, F H, M, L, V L)=[0,0.4,0.4,0.2,0](V H, F H, M, L, V L)=M \\
Y_{S_{2}}=\phi_{Q}(V H, H, M, M, L)=[0,0.4,0.4,0.2,0](V H, H, M, M, L)=M \\
Y_{S_{3}}=\phi_{Q}(M, L, L, L, F L)=[0,0.4,0.4,0.2,0](M, L, L, L, F L)=L \\
Y_{S_{4}}=\phi_{Q}(M, L, L, F L, F L)=[0,0.4,0.4,0.2,0](F H, H, M, L, F L)=L \\
Y_{S_{5}}=\phi_{Q}(H, M, M, F L, V L)=[0,0.4,0.4,0.2,0](F H, H, H, L, F L)=L
\end{gathered}
$$


- $\quad$ Step 2.1.

\begin{tabular}{|c|c|c|c|c|c|}
\hline$S$ & Good 1. & Good 2 & Good 3 & Good 4 & Good 5 \\
\hline$I G_{i}$ & High & Fairly High & Moderate & Low & Very Low \\
\hline$Y_{S}$ & Moderate & Moderate & Low & Low & Low \\
\hline$L C_{1}^{\rightarrow}$ & Moderate & Moderate & Low & Low & Very Low \\
\hline
\end{tabular}

- $\quad$ Step 2.2.

$$
Y_{S}=\phi_{Q}(M, L, L, L, V L)=[0,0.4,0.4,0.2,0](M, M, L, L, V L)=L
$$

With theses steps above, we have obtained a linguistic evaluation (Low) of the solution suppliers in the requirements of the demanded goods.

\section{Criterion 2. Good relationship among the suppliers selected.}

- $\quad$ Step 3.1.

\begin{tabular}{|c|c|c|c|c|c|}
\hline Good 1 & 1 & 2 & 3 & 4 & 5 \\
\hline$R G_{i j}$ & - & Very High & High & Moderate & Fairly Low \\
\hline$R S_{S_{i} S_{j}}$ & - & Very Low & Low & Moderate & Moderate \\
\hline$L I_{1}^{\rightarrow}$ & - & Very Low & Low & Moderate & Fairly Low \\
\hline
\end{tabular}

\begin{tabular}{|c|c|c|c|c|c|}
\hline Good 2 & 1 & 2 & 3 & 4 & 5 \\
\hline$R G_{i j}$ & Fairly High & - & Moderate & Moderate & Low \\
\hline$R S_{S_{i} S_{j}}$ & Very Low & - & Low & Moderate & High \\
\hline$L I_{1}^{\rightarrow}$ & Very Low & - & Low & Moderate & Low \\
\hline
\end{tabular}

\begin{tabular}{|c|c|c|c|c|c|}
\hline Good 3 & 1 & 2 & 3 & 4 & 5 \\
\hline$R G_{i j}$ & Low & Very High & - & Very High & High \\
\hline$R S_{S_{i} S_{j}}$ & Fairly High & Very High & - & High & Low \\
\hline$L I_{1}$ & Low & Very High & - & High & Low \\
\hline
\end{tabular}

\begin{tabular}{|c|c|c|c|c|c|}
\hline Good 4 & 1 & 2 & 3 & 4 & 5 \\
\hline$R G_{i j}$ & Low & Moderate & Very High & - & Very High \\
\hline$R S_{S_{i} S_{j}}$ & High & High & Moderate & - & Low \\
\hline$L I_{1}^{\rightarrow}$ & Low & Moderate & Moderate & - & Low \\
\hline
\end{tabular}

\begin{tabular}{|c|c|c|c|c|c|}
\hline Good 5 & 1 & 2 & 3 & 4 & 5 \\
\hline$R G_{i j}$ & Fairly Low & Moderate & Fairly & Very High & - \\
\hline$R S_{S_{i} S_{j}}$ & High & Fairly & Moderate & Low & - \\
\hline$L I_{1}^{\rightarrow}$ & Fairly Low & Fairly & Moderate & Low & - \\
\hline
\end{tabular}


- $\quad$ Step 3.2.

$$
\begin{gathered}
V_{1}=\phi_{Q}^{I}(M, L, F L, V L)=[0.1,0.5,0.4,0](V L, F L, L, M)=L \\
V_{2}=\phi_{Q}^{I}(M, L, L, V L)=[0.1,0.5,0.4,0](V L, L, L, M)=L \\
V_{3}=\phi_{Q}^{I}(V H, H, L, L)=[0.1,0.5,0.4,0](L, L, H, V H)=M \\
V_{4}=\phi_{Q}^{I}(M, M, L, L)=[0.1,0.5,0.4,0](L, L, M, M)=L \\
V_{5}=\phi_{Q}^{I}(M, L, F L, F L)=[0.1,0.5,0.4,0](F L, F L, L, M)=L
\end{gathered}
$$

- $\quad$ Step 4.

$$
V_{S}=\phi_{Q}(M, L, L, L, L)=[0,0.4,0.4,0.2,0](M, L, L, L, L)=L
$$

With the last three steps, we have obtained a linguistic evaluation (Low) for the relationship among the solution candidates in the post.

Therefore, we have obtained two labels for evaluating the solution S, (Low, Low).

\section{CONCLUDING REMARKS}

The results obtained from this work fall into two clusters. The first consists of the formulation of a suppliers' selection model that could be adapted to the problem under consideration. The second has to do with the establishment of a specific procedure to manage the model, a linguistic selection model.

In addition, as future developments, to point at the following task. The linguistic decision model for suppliers selection provides a bicriteria linguistic evaluation of every candidate for suppliers solution, " $S=\left\{s_{1}, s_{2}, \ldots, s_{m}\right\}$, $s_{i} \in\{1, \ldots, N\}$ ". The future work is to design a search strategy for obtaining a good candidate solution for the problem. The use of searching and optimization techniques as simulated annealing, tabu search or genetic algorithms may be considered for tackling this problem, solving the bicriteria optimization problem associated to the linguistic decision model for suppliers selection.

\section{REFERENCES}

[Arnold, 1996] T. Arnold, Introduction to Materials Management, Prentice Hall (1996).

[Bellandi et al., 1997] G. Bellandi, R. Dulmin and V. Mininno, Study of a Supply Chain from a Buyer/Seller point of view: Planing and Application of an Indicators Model Fuzzy Logic Based, Fuzzy Economic Review 1 (1997), vol. II, 73-89.

[Bonissone and Decker, 1986] P.P. Bonissone and K.S. Decker, Selecting Uncertainty Calculi and Granularity: An Experiment in Trading-off Precision and 
Complexity, in: L.H. Kanal and J.F. Lemmer, Eds., Uncertainty in Artificial Intelligence (North-Holland, 1986), 217-247.

[Delgado et al., 1993] M. Delgado, J.L. Verdegay, and M.A. Vila, On Aggregation Operations of Linguistic Labels, Int. J. Intelligent Systems 8 (1993), 351-370.

[Herrera and Verdegay, 1993] F. Herrera and J.L. Verdegay, Linguistic Assessments in group decision, Proc. First European Congress on Fuzzy and Intelligent Technologies (1993), Aachen, 941-948.

[Herrera et al., 1996] F. Herrera, E. Herrera-Viedma and J.L. Verdegay, Direct Approach Processes in Group Decision Making Using Linguistic OWA Operators, Fuzzy Sets and Systems 79 (1996), 175-190.

[Herrera and Herrera-Viedma, 1997] F. Herrera and E. Herrera-Viedma, Aggregation Operators for Linguistic Weighted Information, IEEE Transactions on Systems, Man and Cybernetics (1997). Part A. systems and Humans, Vol. 27:5 (1997), 646-656.

[Kaufmann and Gil-Aluja, 1992] A. Kaufmann and J. Gil-Aluja, Técnicas de Gestión de Empresa: Previsiones, Decisiones y Estrategias, Pirámide (1992).

[Tong and Bonissone, 1980] M. Tong and P. P. Bonissone, A Linguistic Approach to Decision Making with Fuzzy Sets, IEEE Transactions on Systems, Man and Cybernetics 10 (1980), 716-723.

[Van Weele, 1994] A.J. Van Weele, Purchasing Management: Analysis Planning and Practice, Chapman \& Hall (1994)

[Yager, 1988] R.R. Yager, On Ordered Weighted Averaging Aggregation Operators in Multicriteria Decision Making, IEEE Transactions on Systems, Man and Cybernetics 18 (1988), 183-190.

[Yager, 1992a] R.R. Yager, Fuzzy Screening Systems, Fuzzy Logic: State of the Art, R. Lowen (Ed.), Kluwer Academic Publishers (1993), 251-261.

[Yager, 1995] R.R. Yager, An Approach to Ordinal Decision Making, Int. J. Approximate Reasoning 12 (1995), 237-261.

[Zadeh, 1975] L. Zadeh, The Concept of a Linguistic Variable and Its Applications to Approximate Reasoning-I, Information Sciences 8 (1975), 199249.

[Zadeh, 1983] L. A. Zadeh, A Computational Approach to Fuzzy Quantifiers in Natural Languages, Computers and Mathematics with Applications 9 (1983), 149184 